\title{
Sociologie
}

Sociologie 15(3): 309 - 332

(C) De auteur(s) 2019 (c) CC BY NC ND 4.0 $\ominus$ (5) (c) (7)

https://doi.org/10.5117/soc2019.3.005.zuid

\section{Onderzoeksartikel \\ Worstelen met de markt: de vele gezichten van het neoliberalisme bij Nederlandse beleidsadvies- raden (1998-2005)}

\author{
P.W. Zuidhof \\ Universiteit van Amsterdam \\ zuidhof@uva.nl
}

Keywords: neoliberalisme, governmentality, onafhankelijke beleidsadviesraden

\begin{abstract}
Tre his article studies the quiet rise of neoliberal modes of government in the Netherlands during the 1990s. Using
\end{abstract} a Foucauldian governmentality perspective, it examines twelve reports issued by independent governmental policy advisory councils between 1998 and 2005 to see how they reflected on the changing relationship between the market and government. In response to the growing neoliberalization of Dutch policy, the advisory councils asked how market instruments could be put to better use for attaining public policy goals. Four patterns were identified in their response. First, the advisory councils moved to depoliticize the market question by providing a scientific and rational footing for neoliberal policies. Second, the reports indirectly pointed out that neoliberal policies are not concerned with real markets but play on the market metaphor when designing marketlike solutions for public purposes. Third, it was shown that the neoliberal play on the market metaphor enabled the articulation of a variety of neoliberal interventions, each with distinct political implications. Fourth, it showed how Dutch neoliberal discourse was increasingly being framed around the notion of 'borgen' (safeguarding) of the public interest, in an attempt to realign neoliberal policies with the public interest. These findings challenge popular explanations that tend to view 'neoliberalism' as a grand ideology or policy agenda but point at the everyday role of policy advice in the making of neoliberal forms of government. 
Daarmee had zich een omslag voorgedaan. Het publieke debatstond onverwachts in het teken van de markt en de voordelen van het marktmechanisme. Waar de overheid ten tijde van de verzorgingsstaat veel verantwoordelijkheden aan zich trok en de behartiging daarvan ook aan zich hield, werden nu vooral de voordelen van de private sector belicht. Het politieke tij was gekeerd. [...] In het buitenland ging deze omslag soms met veel rumoer gepaard (Thatcher, Reagan). In Nederland leek er van een debat soms nauwelijks sprake [...] Dit betekende niet dat er niets gebeurde. Vrij geruisloos zijn op verschillende terreinen indrukwekkende veranderingen tot stand gebracht [...]. (Wetenschappelijke Raad voor het Regeringsbeleid 2000: 17)

\section{Inleiding}

Het neoliberalisme en haar geschiedenis, ook die in Nederland, blijft een enigma. Wat is 'het neoliberalisme' en hoe kon het, met name sinds de jaren tachtig, zo wijdverbreid raken? In de populaire beeldvorming wordt het neoliberalisme vaak uitgelegd door te verwijzen naar grote ideologische debatten, denkers zoals Hayek en Friedman, politieke actoren zoals Reagan en Thatcher, internationale organisaties zoals IMF en The World Bank, think tanks zoals de Mont Pèlerin Society, het Britse Adam Smith Institute en de invloed van het bedrijfsleven, zoals bijvoorbeeld de gebroeders Koch (bijv. Achterhuis 2010; Steger en Roy 2010). Volgens dit populaire narratief hebben 'de neoliberalen' 'het neoliberalisme' tussen 1930 en heden verspreid en zo een 'neoliberale revolutie' ontketend (Harvey 2005). In de laatste tien jaar is deze simplistische weergave gelukkig voorzien van de broodnodige theoretische en historische details (bijv. Mirowski en Plehwe 2009; Peck 2010; Burgin 2012; Mirowski 2013; Brown 2015; Slobodian 2018; Reinhoudt en Audier 2018). In navolging hiervan bestudeert dit artikel de opkomst van neoliberale beleidsvormen in Nederland die niet onmiddellijk berusten op grote ideeën en grote politieke denkers, maar op de alledaagse, praktische inbreng van beleidsmakers. Dit gebeurt aan de hand van een onderzoek naar het Nederlands beleidsdebat over marktwerking in de periode rondom de eeuwwisseling.

Over de 'neoliberale' revolutie van de jaren negentig in Nederland is nog maar weinig bekend. Dat is opvallend, want zoals de Wetenschappelijke Raad voor het Regeringsbeleid (WRR) hierboven al schetst, is in deze periode een ingrijpende marktwerkingsagenda in gang gezet. In deze periode vonden in verscheidene sectoren liberaliserings- en privatiseringsprojecten plaats, onder andere in de telecommunicatie, het openbaar vervoer, energiemarkten, maar ook in minder in het oog springende sectoren zoals de taximarkt of de advocatuur. Ook binnen zorg en onderwijs introduceerde en organiseerde de overheid marktwerking. Vrijwel al deze hervormingen volgden uit het project Marktwerking, Deregulering en Wetgevingskwaliteit (MDW) dat ten tijde van het eerste kabinet-Kok in 1994 was gelanceerd door het Ministerie van Economische Zaken in samenwerking met het 
Ministerie van Justitie. In de jaren negentig voltrok zich aldus in veel opzichten ook in Nederland een stille, neoliberale revolutie (vgl. Jabko 2006). Deze sluipende neoliberalisering van het Nederlands overheidsbeleid roept de vraag op waar die revolutie precies uit bestond en welke ideeën, actoren en belangen daarin een rol hebben gespeeld (Oudenampsen en Mellink 2019).

Aan het einde van de jaren negentig bracht een aantal onafhankelijke Nederlandse beleidsadviesraden een reeks adviezen uit over de verschillende marktwerkingsprojecten. Tussen 1998 en 2005 publiceerden beleidsadviesraden zoals de eerdergenoemde WRR, de Sociaal-Economische Raad (SER) en een aantal ministeriele adviesraden verscheidene rapporten die rechtstreeks ingingen op de veranderende verhouding tussen markt en overheid. ${ }^{1}$ Deze rapporten vormen een goede graadmeter over hoe er rond de eeuwwisseling in bestuurlijke kringen werd gereflecteerd op nut en noodzaak van de marktwerkingsprojecten. Hoe verhielden de adviesraden zich tot de veranderende verhouding tussen markt en overheid? Onderkenden zij een trend tot neoliberalisering in de wijze van besturen? Namen zij afstand van deze ontwikkeling of droegen ze juist bij aan het formuleren van nieuwe, neoliberale oplossingen? Hoe kwamen deze eventuele neoliberale oplossingen dan in de rapporten tot uitdrukking? En in hoeverre was hun reactie specifiek voor Nederland?

Om deze vragen te onderzoeken maak ik in dit artikel gebruik van een benadering ontleend aan Foucaults studie naar liberale en neoliberale bestuursrationaliteiten (2007; 2008). Foucault introduceerde de term bestuursrationaliteit (governmentality) in 1978/79 in zijn lezingen aan het Collège de France. Hij onderscheidde liberale bestuursrationaliteiten van neoliberale bestuursrationaliteiten en betoogde dat beide een andere historisch vorm van het praktiseren, denken en legitimeren van bestuur vertegenwoordigden. Kenmerkend voor neoliberale bestuursrationaliteiten was volgens Foucault, dat deze de markt tot leidend principe van bestuur verhieven (zie ook Brown 2015; Zuidhof 2014; Zuidhof 2019). Dit in tegenstelling tot eerdere, zogenaamde liberale bestuursrationaliteiten waarin de markt in eerste instantie slechts het object van bestuur vormde. In tegenstelling tot liberale vormen van bestuur die in essentie marktregulerend van aard zijn, onderscheiden neoliberale vormen van bestuur zich door een marktconstructivistisch karakter waarbij markten worden gemaakt én gebruikt als middel en norm voor bestuur.

Voor dit artikel heb ik twaalf adviesrapporten onderworpen aan een discoursanalyse om na te gaan of en op welke wijze deze rapporten een neoliberale bestuursrationaliteit formuleren. Voor de analyse zijn alle rapporten geselecteerd die in een periode rondom de eeuwwisseling zijn opgesteld door bij wet ingestelde onafhankelijke beleidsadviesraden en die expliciet de verhouding tussen markt en

1 Voor achtergrond van de rol van beleidsadviesraden in Nederland, zie bijvoorbeeld Den Hoed (1995) of Hoppe en Halffman (2004). 
staat behandelen (zie lijst in bijlage). Ten eerste worden de probleemstellingen van de rapporten geïnventariseerd om vast te stellen wat volgens de adviesraden het maatschappelijke vraagstuk is. Vervolgens wordt onderzocht hoe in de rapporten op dit maatschappelijke vraagstuk wordt gereflecteerd. Nemen de adviesraden een tendens tot neoliberalisering van de bestuursrationaliteit waar en zo ja, hoe reageren zij daarop? In het tweede deel van het artikel analyseer ik hoe de rapporten hun adviezen formuleren om de bestuursrationaliteit bij te sturen. Welke aspecten daarvan moeten behouden blijven, wat is voor verbetering vatbaar? Kunnen uit de adviezen algemene patronen of motieven worden gedestilleerd over de wijze waarop de adviesraden de verhouding tussen markt en overheid (her)definiëren? En hoe figureert daarin het idee van de markt? Het doel van het artikel is om een empirisch rijker en veelvormig neoliberalisme te laten zien, om zo meer zicht te krijgen op de micropolitieke aspecten van de sluipende neoliberalisering in Nederland in de jaren negentig.

\section{Een nieuw bestuurlijk probleem: markten als instrument van bestuur}

Aan het einde van de jaren negentig bracht een aantal onafhankelijke beleidsadviesraden adviesrapporten uit over de veranderende verhouding tussen overheid en markt. Het vormde daarmee een duidelijk politiek signaal, want in vrijwel alle onderzochte gevallen werd het rapport opgesteld naar aanleiding van een concrete adviesaanvraag vanuit een van de ministeries. Over welke vraagstukken werden de adviesorganen gevraagd zich te buigen? Bijlage 1 geeft een overzicht van de probleemstellingen en de aard van de adviezen in de onderzochte rapporten. Op basis hiervan springt een aantal overeenkomsten in het oog.

Ten eerste behandelen alle rapporten een zeer vergelijkbare onderzoeksvraag: wat zijn de mogelijkheden en beperkingen van de toepassing van markten en marktwerking voor de uitvoering van publieke taken. Zo onderzocht de Raad voor Openbaar Bestuur (ROB) in De overheid de markt in- of uitprijzen 'of, en onder welke voorwaarden, publieke dienstverlening aan marktwerking onderhevig kan zijn' (1998: 2). In het invloedrijke rapport Het borgen van publiek belang uit 2001, stelde de WRR de vraag hoe in een context van privatisering en een toenemend beroep op de private sector, de publieke belangen het best behartigd konden worden. Andere raden onderzochten voor hun specifieke sector of, en op welke wijze markten het best een plaats konden krijgen binnen de uitvoering van de publieke taken, zoals het onderwijs, de infrastructuur of de zorg. Al deze rapporten onderzochten en beoordeelden dus de reikwijdte van de markt als overheidsinstrument voor de uitvoering van publieke taken.

Ten tweede blikten alle onderzochte rapporten terug op eerdere ervaringen met de toepassing van marktwerking en bepleitten ze een meer systematische aanpak. Zo blikte de ROB in haar rapport De overheid de markt in- of uitprijzen terug op reeds in gang gezette MDW-projecten en stelde ze dat in deze projecten te eenzijdig 
werd gekozen voor overheid of markt: 'Het ware daarom verstandig, zo meent de Raad, de focus van de MDW-operatie te heroverwegen en te verbreden' (1998: 4). Ze stelde voor om een aantal algemene principes op te stellen 'voor een systematische aanpak van keuzes rond de (verdergaande) introductie van marktwerking' (ibid.: 5). De WRR meende eveneens dat 'nadere analyse van de toedeling van publieke en private verantwoordelijkheden' geboden was 'omdat privatisering in de praktijk niet altijd de resultaten heeft die daarmee vooraf werden beoogd' en er 'zelfs twijfel [is] ontstaan aan de juistheid van een verdere verschuiving van verantwoordelijkheden' (2000: 22). De Raad voor Verkeer en Waterstaat (RVW) achtte het begrijpelijk 'dat de eerste ervaringen met marktwerking voor enige onrust zorgen,' maar 'om daarom nu gas terug te nemen, zou [...] een historische vergissing zijn' (2000: 3). De Raad wilde daarentegen duidelijkheid verschaffen over 'de gebieden waar marktwerking nodig is en het type overheid wat daarbij nodig is' (ibid.: 3).

De rapporten leken in hun aanbevelingen niet alleen op elkaar, maar die aanbevelingen vormden bovendien een reactie op eerdere toepassingen van markten voor publieke doelen. Alle adviesraden poogden dus een antwoord te formuleren op een reeds bestaande, sluipende neoliberalisering en hoopten deze op de een of andere manier te herijken. Hierbij vertrokken de rapporten niet vanuit de (door Foucault geïdentificeerde) liberale vraag van marktregulering: hoeveel moet of mag de overheid ingrijpen op markten om marktfalen aan te pakken? In plaats daarvan onderzochten de rapporten een neoliberale vraag over maakbare markten en de wijze waarop deze publieke doelen kunnen dienen. Zo besprak de RVW in Meer markt, andere overheid de mogelijkheden en beperkingen van 'marktwerking als oplossing voor overheidsproblemen' (2000: 12). En in het rapport van de ROB werd de neoliberale vraag zelfs letterlijk uitgespeld:

Met het begrip 'marktwerking' wordt in de adviesaanvraag, zo interpreteert de Raad, gedoeld op de ontdekking en het gebruik van marktmechanismen als instrument om publieke doelen te realiseren, waardoor de klassieke verhouding tussen markt en overheid verandert. (ROB 1998: 9, cursivering toegevoegd)

Ook in de behandeling van deze onderzoeksvragen vertoonden de rapporten van de verschillende adviesorganen veel overeenkomsten. Telkens probeerden de auteurs kaders te ontwerpen waarbinnen de markt voor overheidsdoeleinden kon worden ingezet, zonder dat het publieke belang hierdoor werd geschaad. De oplossingen die zij vonden varieerden onderling. Zo maakte de ROB zich sterk voor een toezichthoudende overheid: 'De introductie van marktwerking bij de uitvoering van publieke taken houdt risico's in voor doelmatige en rechtmatige uitvoering. Daarom is toezicht van groot belang' (1998: 2). De Raad voor Volksgezondheid en Zorg (RVZ) betoogde daarentegen in Tussen markt en overheid (1998) dat marktwerking in de zorg gestalte moest krijgen via 'gedeeld bestuur.' De overheid werd in dit voorstel dus veel minder op afstand geplaatst. Ook de RVW (2000) bepleitte marktwerking, maar waarschuwde dat de overheid zich hierdoor sterker moest opwerpen als hoedster van 
het algemeen belang. En in Borgen van publiek belang stelde de WRR dat de overheid moest waken over de borging van publieke belangen wanneer zaken aan de markt werden overgelaten of marktwerking werd geïntroduceerd.

Uit deze eerste inventarisatie van de probleemstellingen van de onderzochte rapporten komt naar voren dat de adviesorganen reageerden op een reeds in gang gezette neoliberalisering van de bestuursrationaliteit. Blijkbaar voorzagen ze in een destijds bij de overheid levende behoefte aan reflectie op deze - tot op dat moment - stilzwijgende ontwikkeling. Moest deze ontwikkeling worden ingekaderd of bijgestuurd? In de praktijk beperkten de adviesraden zich echter niet tot onderzoek alleen: via hun probleemanalyse en hun aanbevelingen beoogden ze actief bij te dragen aan de inkadering en vormgeving van een neoliberale bestuursrationaliteit. In het vervolg van dit artikel wordt hun actieve bijdrage nader tegen het licht gehouden aan de hand van vier typerende, telkens terugkerende patronen waarmee marktgericht beleid werd geïmplementeerd.

\section{Patroon 1: het marktvraagstuk depolitiseren}

Veel marktwerkingsrapporten begonnen hun analyse met het depolitiseren van het marktvraagstuk. Dit gebeurde op een aantal verschillende manieren. Ten eerste namen veel adviescommissies expliciet afstand van ideologische overwegingen. Zo schreef de WRR in haar rapport Het borgen van publiek belang:

Ideologische argumenten dreigen de discussie soms te overheersen. Daarmee gaat het niet meer om een heldere afweging van argumenten, maar lijkt het slechts te gaan om een wedstrijd tussen 'overheid en markt.' (WRR 2000: 17)

Om het debat uit de ideologische sfeer te halen, stelde de WRR een meer 'objectieve analyse' voor. In het 'debat over privatisering' moest volgens de Raad 'ideologie worden vermeden'. In plaats daarvan moest de overheid proberen privatisering 'op een meer objectieve wijze te toetsen', zodat 'de kwaliteit van de behartiging van publieke belangen' kon worden verbeterd (2000: 22).

De RVW depolitiseerde de marktwerkingsdiscussie door te stellen dat het debat over de wenselijkheid van marktwerking vaak te simpel wordt voorgesteld:

Men kiest voor blauwdrukken die binnen een bepaalde termijn bereikt dienen te worden en vervolgens is men verbaasd als dat niet lukt. Waarna de politiek niet zelden besluit tot uitstel of andere rigoureuze ingrepen, veelal aan de hand van media-aandacht over incidenten. (RVW 2004: 11)

Er bestonden volgens de RVW in de politiek 'nogal wat misverstanden' over marktwerking en 'wordt marktwerking vaak tot doel verheven,' terwijl het bij de toepassing in overheidssituaties 'geen doel maar een middel' zou moeten zijn' 
(2000: 13). Elders stelde de Raad letterlijk voor om het debat te depolitiseren: 'Veranderingen in de marktordening [...] zijn naar het oordeel van de Raad [...] gebaat bij een verdere ont-politisering en ont-ideologisering van het veranderingsproces' (RVW 2004: 68).

In de adviesrapporten werd de marktwerkingsdiscussie verder gedepolitiseerd door het aanbieden van een systematisch 'denkkader' dat de discussie een wetenschappelijke en onpartijdige basis moest geven:

Het roept de vraag op of het mogelijk is om het debat over privatisering te verhelderen. De WRR wil in dit rapport daartoe een poging doen. Dit rapport levert overigens niet alleen een denkkader voor privatisering. De Raad geeft ook aan welke aspecten bij de discussie over privatisering speciale aandacht vragen. (WRR 2000: 18)

Op vergelijkbare wijze constateerden ook de Energieraad en de Raad voor Verkeer en Waterstaat het gebrek aan een 'samenhangend analysekader' om op een 'gefundeerde manier analyses te maken over de effecten van liberalisering en marktordening' (ER en RVW 2003:5). Als oplossing voor dit type probleem maakte de WRR gebruik van het bekende onderscheid in economisch beleid tussen 'politieke' vragen en 'wetenschappelijke' vragen:

Aldus staat in dit rapport de hoe-vraag (de wijze van behartigen van publieke belangen) centraal. In tegenstelling tot de bij uitstek politieke wat-vraag leent de hoe-vraag zich veel beter voor een verhandeling vanuit wetenschappelijke hoek. Verschillende wetenschappen leveren argumenten voor een optimale behartiging van publieke belangen. (WRR 2000: 23)

Aldus werd de neoliberale vraag over de inzet van markten voor publieke doelen de facto tot objectief wetenschappelijk vraagstuk verheven. Het gevolg van deze 'nette' arbeidsdeling tussen politiek en wetenschap was dat de politieke dimensie van het marktvraagstuk uit beeld verdween.

De beleidsadviesraden erkenden dus de politieke lading van de vraag die hen vanuit de overheid was voorgelegd. Ze reageerden hier echter op met een poging het project te depolitiseren. Door marktwerkingsvraagstukken in te kaderen en te voorzien van een wetenschappelijke basis droegen de adviesraden bij aan een verdere rationalisering van het neoliberale marktwerkingsproject. Met deze depolitiserende aanpak versterkten de beleidsadviesraden bedoeld of onbedoeld een neoliberale bestuursrationaliteit. Het dient als voorbeeld waaruit blijkt dat het neoliberalisme als politiek project niet alleen tot stand kwam op basis van grote ideeën en vooraanstaande denkers. Veel neoliberale ingrepen kwamen eerder voort uit het soort stille gedepolitiseerde en technocratische interventies zoals onder andere van deze wetenschappelijke adviesraden. 


\section{Patroon 2: spelen met de 'markt' en marktwerking}

Het tweede patroon dat kenmerkend is voor de wijze waarop de adviesraden het marktvraagstuk benaderden, is hun omzichtige en zelfbewuste wijze van verwijzen naar de markt. Het is opmerkelijk hoe vaak het begrip 'markt' bijvoorbeeld tussen aanhalingstekens werd geplaatst in de adviesrapporten. Adviesraden deden dit onder andere om te markeren dat de 'markt' een geladen begrip was in politieke debatten: 'Deze vraag naar het "voor" of "tegen" is overigens wel kenmerkend voor de manier waarop het debat vaak wordt gevoerd', constateerde de WRR, 'namelijk ideologisch voor of tegen "de markt"' (WRR 2000: 162). Ook plaatsten de auteurs de 'markt' soms tussen aanhalingstekens om aan te geven dat zij een theoretische abstractie is: 'Onder het theoretisch begrip "markt" wordt over het algemeen de marktvorm volkomen concurrentie verstaan' (RVZ 1998: 18).

In de meeste gevallen spraken de adviesraden echter van een 'markt' tussen aanhalingstekens om te benadrukken dat het in de besproken sectoren geen sprake was van échte, of volwaardige markten. Zo stelde de RVZ: 'In de dagelijkse praktijk van de Nederlandse gezondheidszorg is eigenlijk nooit sprake van volledige marktwerking, maar van meer of minder marktconform handelen' (RVZ 1998: 35). In een later rapport merkte de Raad op: 'De zorgmarkt is geen gewone markt' (RVZ 2003: 15). Ook de Onderwijsraad (OR) constateerde in een verkenning: 'Er is dan ook op dit moment van een "echte" onderwijsmarkt geen sprake [...] De onderwijsmarkt wordt daarom wel een quasi-markt genoemd' (OR 2001b: 19), en de RVW stelde in een rapport uit 2004 dat infrastructurele veranderingsprocessen 'in veel gevallen weinig tot niets met "echte" marktwerking te maken hebben' (RVW 2004: 11).

De aanhalingstekens rondom de 'markt' maakten impliciet duidelijk dat het in de onderhavige gevallen niet ging om daadwerkelijke bestaande markten, maar juist om de neoliberale toepassing van marktoplossingen en marktlogica binnen deze sectoren. Het scheppen van een volledige markt was overigens in alle gevallen bij voorbaat uitgesloten: wanneer 'de markt' fungeert als bestuurlijk instrument, is zij in de eerste plaats een metafoor voor praktijken die 'als een markt' of 'marktachtig' zijn of moeten worden. Ook andere formuleringen onderstreepten dat de besproken adviesraden zich welbewust waren van het geconstrueerde karakter van neoliberale marktwerking. Zo sprak de WRR bijvoorbeeld over 'het scheppen van de markt' en 'de overgang van overheidsbeheer naar geconditioneerde marktwerking.' Elders schreef de Raad dat 'het geloof in de maakbaarheid van de samenleving uit de jaren zeventig verdwenen mag zijn [maar dat] het geloof in de maakbaarheid van de markt in de jaren negentig nog springlevend is.' Bovendien verzuchtte de Raad: 'In werkelijkheid blijkt die "markt" echter maar heel moeizaam te creëren' (WRR 2001: 158-159). De verwijzingen naar 'de markt' tussen aanhalingstekens zijn hier geen speelse versieringen, maar markeren een wezenlijk aspect van de neoliberale bestuursrationaliteit: de doelgerichte inzet van de markt of aan de markt ontleende aspecten als instrument voor overheidsbeleid. 
De meest treffende uitdrukking van deze neoliberale bestuursrationaliteit is ongetwijfeld het begrip 'marktwerking'. In plaats van te verwijzen naar het invoeren van markten, sprak men in de rapporten liever over het introduceren van 'marktwerking'. Een snelle telling leert dat het begrip 'marktwerking' in de bestudeerde rapporten het meest voorkomende begrip is na 'markt' of 'markten'. Het begrip 'marktwerking' is ook kenmerkend voor Nederland, in die zin dat er geen rechtstreekse vertaling van bestaat in het Engels en een aantal andere talen. Het begrip drukt echter heel kernachtig uit dat het bij neoliberale toepassingen gaat om de werking van de markt en niet de markt zelf. De ROB, zoals hierboven al aangehaald, was zich hier zeer van bewust: 'Met het begrip "marktwerking” wordt [...] gedoeld op de ontdekking en het gebruik van marktmechanismen als instrument om publieke doelen te realiseren' (ROB 1998: 11). Het begrip 'marktwerking' staat dus synoniem voor de neoliberale toepassing van de markt als instrument voor publieke doeleinden.

Het begrip 'marktwerking' is nog om een andere reden aantrekkelijk: meer dan het begrip 'markt' toont het ambiguïteit. Want waaruit bestaat de 'werking' van de markt nu precies? Het kan worden aangewend voor een reeks van neoliberale beleidsinterventies: marktconforme maatregelen, maatregelen die betrekking hebben op quasimarkten, de implementatie van marktmechanismen, de introductie van marktdenken, het volgen van marktprincipes, maar ook bijvoorbeeld vraaggestuurd of aanbodgestuurd beleid, marktprikkels, concurrentie of concurrentieverhogende maatregelen. Zoals de RVZ letterlijk constateerde, gaat het bij marktconform beleid om 'aan de markt of aan marktwerking ontleende elementen - zoals competitie, ondernemend handelen, het lopen van bedrijfsrisico, besluitvorming door individuele producenten en consumenten - [...] toegepast binnen het kader van overheidsregulering' (1998: 35). Het begrip 'marktwerking' functioneert hier als politiek handig en uitgesproken Nederlands eufemisme voor neoliberale interventies. Het is politiek handig omdat het bijdraagt aan een verdere depolitisering en ontideologisering van de discussie rondom 'de markt'. En het is ook politiek handig omdat het beleidsmatig ambigu is en geen eenduidige markttoepassing voorschrijft, maar juist ruimte laat voor een veelheid van marktachtige en aan de markt ontleende bestuurlijke ingrepen.

Het taalkundige spel met begrippen als 'de markt' en 'marktwerking' vervulde in de adviesrapporten dus een specifieke functie: zij articuleerden marktachtige elementen die een bestandsdeel konden vormen van een neoliberale bestuursrationaliteit. Zoals hieronder zal blijken gaf dit neoliberale spel aanleiding tot een veelheid van uiteenlopende beleidsmaatregelen die weliswaar allemaal zijn geïnspireerd op de markt, maar daarvan heel verschillende deelaspecten benadrukten.

2 Zie voor een telling: Zuidhof (2012: 237). 


\section{Patroon 3: neoliberale performances en de vele gezichten van het neoliberalisme}

Het derde patroon dat naar voren kwam uit de bestudeerde beleidsrapporten is de zeer uiteenlopende wijze waarop marktwerking van sector tot sector en van situatie tot situatie betekenis kreeg. De adviesraden wierpen in hun onderzoeksrapporten geregeld de vraag op hoe 'de markt' (of aspecten daarvan) in een specifieke sector aan invloed kon winnen. Verwijzingen naar de verschillende betekenissen van de markt of marktwerking speelden hierbij een cruciale rol. Sommige rapporten benadrukten bijvoorbeeld de vraagaspecten van de markt en bevalen vraagsturing aan, terwijl andere rapporten de nadruk legden op consumentenbelangen en keuzevrijheid. Weer andere rapporten beklemtoonden het belang van concurrentie en haar betekenis voor efficiëntie en innovatie, of richtten de aandacht op vrij goederenverkeer of vrije contractvorming. De neoliberale toepassing van de markt kende dus vele facetten en gezichten.

Deze verschillende aan het beeld van de markt ontleende interventies worden hier neoliberale marktperformances genoemd. Verschillende neoliberale performances lichtten elk een ander aspect van de markt uit, om het vervolgens aan te wenden als beleidsinstrument ter realisatie van een publiek doel. Ze worden hier aangeduid als performances vanwege de wijze waarop zij nieuwe bestuurlijke werkelijkheden beogen te constitueren, zoals zal blijken uit een aantal voorbeelden.

De RVZ steunde in haar beleidsrapporten bijvoorbeeld voornamelijk op vraaggerichte performances. In Tussen markt en overheid (1998) onderzocht de RVZ hoe de overheid moest omgaan met 'de spanning tussen markt en aanbodregulering' (ibid.: 9). Naar aanleiding van de commissie-Dekker waren al veel stappen gezet 'om elementen van marktwerking zoals competitie en ondernemend gedrag aan het bestaande systeem toe te voegen en daardoor de behoefte aan aanbodregulering te verminderen' (ibid.: 26), oordeelde de Raad. Volgens de RVZ legde vraagsturing het echter nog te vaak af tegen kostenbeheersing en aanbodregulering, wat zou blijken 'uit te lange wachtlijsten en verschraling van zorg, een ondoelmatige organisatie en uitvoering van de zorg en een zwakke positie van de patiënt' (ibid.: 36). Daarom moest volgens de RVZ het evenwicht tussen marktwerking en overheidsregulering in de richting van de markt verschuiven (ibid.: 5-6), opdat 'individuele patiënten zelf meer keuzen [...] kunnen maken over de zorg die ze krijgen' (ibid.: 38). In een context waarin het aanbod sterk gereguleerd was, zag de RVZ in marktwerking vooral de voordelen van vraagsturing en de keuzevrijheid van de consument.

Ook in het toepasselijk getitelde RVZ-rapport Van patiënt tot klant (2003) stonden vraaggerichte performances centraal. Allereerst constateerde de Raad dat 'de zorgmarkt [...] geen gewone markt' was en dat de rol van de cliënt in de zorg verschilde van die van een klant op 'een "gewone" consumentenmarkt' (ibid.: 15). Niet alleen de tussenkomst van verzekeraars makkte de markt meer complex, maar ook de hoge mate en uitgebreide vormen van aanbodregulering maakten dat 'cliënten te weinig mogelijkheden (marktmacht) [hebben] om de aanbieders van 
zorg adequaat te kunnen sturen' (ibid.: 19). Vervolgens deed de Raad een aantal voorstellen om binnen deze ongewone marktstructuur 'nieuwe prikkels' in het stelsel in te bouwen die de zorgverlening meer klantgericht moesten maken. De overheid moest:

[...] bevorderen dat de cliënt in de zorgsector waar mogelijk een klantrelatie krijgt, zoals dit ook in andere sectoren het geval is. In andere sectoren betekent een klantrelatie dat de klant prijs en kwaliteit vergelijkt, en voor een product of dienst betaalt. Ook in de zorgsector zouden cliënten prijs en kwaliteit van de zorg moeten kunnen vergelijken. (RVZ 2003: 59)

De cliënt zou volgens de RVZ de keuze moeten krijgen om zorg in natura dan wel op restitutiebasis af te sluiten, waar mogelijk door middel van een persoonsgebonden budget. Ook zou de 'betaalrelatie' moeten worden versterkt via het invoeren van eigen bijdragen en de mogelijkheid tot terugvorderen. Daarnaast bepleitte de Raad nieuwe randvoorwaarden die afdwongen dat 'de zorgaanbieder [...] zich op marktconforme wijze door de behoefte van de cliënt laat leiden,' door 'organisaties van cliënten/patiënten' in staat te stellen 'de prestaties van zorgaanbieders in beeld te brengen' in situaties waar geen rechtstreekse keuze mogelijk was (ibid.: 63). In Van patiënt tot klant legde de RVZ marktwerking dus vrijwel uitsluitend uit als meer vraagsturing: het laten leiden door 'wat de cliënten willen en belangrijk vinden' (ibid.: 11). Het beleidsvoorstel was daarmee een voorbeeld van een neoliberale performance waar het vraag- of consumentaspect van de markt werd ingezet als beleidsinstrument voor het realiseren van publieke doelen in de zorg.

In tegenstelling tot de vraaggerichte benadering van de RVZ benadrukten de neoliberale performances van de RVW vooral het concurrentieaspect van de markt. In een adviesrapport uit 2000 erkende de Raad de consumentenlogica door op te merken dat 'de markt over betere middelen [beschikt] om te weten wat mensen willen dan de overheid' (RVW 2000). Vervolgens benadrukte de Raad echter vooral het concurrentieaspect van de markt: 'De Raad vindt marktwerking [...] vooral van belang voor innovatie en differentiatie van producten en diensten' (ibid.: 4). Ze wees het stimuleren van concurrentie aan als aangewezen instrument:

Het aanbod van diensten kan dan onder concurrentie plaatsvinden, zodat de overheid op dat niveau geen bemoeienis meer behoeft te hebben met de afstemming van vraag en aanbod. Dat schept ruimte voor innovatie, diversificatie en kwaliteitsverbetering. (RVW 2000: 6)

De rol van de overheid zou zich aldus moeten richten op het 'ordenen, sturen, controleren en arbitreren' (ibid.: 7) en het 'waarborgen van effectieve concurrentie' (ibid.: 5).

De RVW adviseerde om het concurrentiebeginsel vooral in te zetten binnen zogenaamde netwerksectoren. Ze onderscheidde hierbij concurrentie tussen 
infrastructuren, concurrentie op infrastructuren en concurrentie om infrastructuren' (ibid.: 6). Bij deze drie vormen van concurrentie moest de overheid volgens de adviesraad verschillende ingrepen doen om haar publieke doelen veilig te stellen:

De Raad geeft aan waarop de overheid speciaal moet letten bij deze concurrentievormen: de totstandkoming van noodzakelijke investeringen bij concurrentie tussen infrastructuren; voor ieder gelijke toegankelijkheid van de voorziening bij concurrentie op een infrastructuur; de eisen waaraan de dienstverlening moet voldoen bij concurrentie om een infrastructuur. (RVW 2000: 6)

Ook infrastructuren die van oudsher als natuurlijke monopolies werden gezien, konden door functiescheiding (tussen netwerkbeheer en gebruikers van het netwerk) en technologische verandering, wel 'aan enige vorm van concurrentie worden onderworpen' (ibid.: 17):

In bijna alle sectoren doen zich dus technologische (en culturele) ontwikkelingen voor die gaan in de richting van meer concurrentie en meer differentiatie. Hiermee zou rekening moeten worden gehouden bij het vaststellen van een concurrentie-regime voor een sector. Het moet mogelijk zijn over te stappen naar een regime met meer concurrentie, wanneer dat technologisch kan en maatschappelijk gewenst is. (RVW 2000: 18)

In het rapport werd daartoe een gedetailleerde 'concurrentieladder' geïntroduceerd, om te analyseren onder welke omstandigheden meer concurrentie kon worden bereikt (ibid.: 21). Ook presenteerde de RVW een matrix waarin verschillende vormen van concurrentie (van quasiconcurrentie door vergelijkingen, periodieke concurrentie bij concurrentie om de markt en continue concurrentie op de markt) werden gerelateerd aan verschillende fasen van liberalisatie (ibid.: 24). Deze vormen van concurrentie werden vervolgens toegepast op concrete sectoren: de telecommunicatie, het openbaar vervoer en het wegennetwerk. Al met al zijn deze concurrentieladder en concurrentiematrix goede illustraties van de wijze waarop de RVW creatief speelde met het concurrentieaspect van de markt. De Raad zocht de neoliberale performance dus vooral in een toename van concurrentie, dat als breed inzetbaar bestuursinstrument aan de overheid werd aanbevolen.

Naast deze twee uitgesproken vormen van vraag-neoliberalisme bij de RVZ en concurrentie-neoliberalisme bij de RVW, maakten ook andere neoliberale performances hun opwachting in de adviesrapporten. Sommige rapporten braken bijvoorbeeld een lans voor aanbodgericht beleid. Marktwerking werd hier opgevat als een versterking van de positie van private partijen. De WRR onderzocht bijvoorbeeld of 'bepaalde elementen van het marktmechanisme ook binnen het publieke domein, de overheid, een plaats kunnen hebben': 'In overeenstemming met het algemeen spraakgebruik zal in het vervolg het begrip "markt" steeds op 
de private sector worden betrokken, tenzij uitdrukkelijk anders wordt aangegeven' (WRR 2000: 26). De WRR interpreteerde marktwerking hier in de eerste plaats als privatisering. De RVW gebruikte het begrip echter voor verzelfstandiging, dat de Raad nadrukkelijk van privatisering onderscheidde:

De noemer waaronder de veranderingsprocessen in infrastructuurgebonden sectoren zich voltrekken heet: het bevorderen van marktwerking. Nadere beschouwing van de veranderingsprocessen, die tot dusver onder deze noemer zijn ingezet, leert echter dat zij in veel gevallen weinig tot niets met 'echte' marktwerking te maken hebben, in de zin van vrijgeven voor onderlinge concurrentie (liberalisering) en/of het overbrengen van de publieke naar de private sector (privatisering). Vaak gaat het in de praktijk vooral om organisatorische verzelfstandiging binnen de publieke sector, in de zin van het 'op afstand zetten van de politiek', waarbij de betreffende uitvoeringsorganisaties tot het overheidsdomein blijven behoren. (RVW 2004: 12-13)

Weer een andere vorm van aanbod-neoliberalisme die in de rapporten naar voren kwam bestond uit het benadrukken van 'ondernemerschap' (bijvoorbeeld 'nieuw (publiek) ondernemerschap' (WRR 2001:96), of 'ondernemend gedrag' (RVZ1998:3)), of het wijzen op een winstoogmerk (bijvoorbeeld bij professionals zoals advocaten of medisch-specialisten (WRR 2001: 80)). Dit laatste stond bijvoorbeeld centraal in het SER-advies Ondernemerschap voor de publieke zaak (2005), waarin werd onderzocht hoe de publieke dienstverlening in de zorg, het onderwijs of bij woningcorporaties, verbeterd kon worden door het stimuleren van ondernemerschap.

Weerandereinterpretatiesvan marktwerkingaccentueerden hetgoederenaspect, bijvoorbeeld door publieke diensten als verhandelbare goederen voor te stellen. Een voorbeeld hiervan was het advies Marktwerking in de medisch specialistische zorg (2003) waarin de RVZ onderzocht hoe diagnosebehandelcombinaties (DBCs) het best in de zorg konden worden geïntroduceerd: 'De sleutel tot het in gang zetten van marktwerking is een selectieve invoering van DBC's' (ibid.: 6). Onder het (markt-constructivistische) kopje 'Marktwerking in de Maak' stelde de Raad dat de systematiek van functionele budgettering aan vervanging toe was en dat DBC's de 'beoogde opvolgers' waren omdat zij het mogelijk maken dat 'partijen met elkaar onderhandelen over de prijs van dienstverlening' (RVZ 2003: 22):

De DBC's zijn als het ware de producten en diensten die specialisten en ziekenhuizen aan hun patiënten kunnen bieden. Het is de bedoeling dat verzekeraars met ziekenhuizen over de prijs van die DBC's gaan onderhandelen. Ziekenhuizen krijgen dan betaald naar de aard, de omvang en de kwaliteit van hun diensten. (RVZ 2003: 5)

Verwant aan deze op goederen gerichte performance waren performances die marktwerking vooral bezagen in relatie tot ruil en ruilverhoudingen. Dit 
speelde onder andere in het hierboven besproken rapport Van patiënt tot klant (2003) waarin werd onderzocht hoe door een institutionele herordening van de verhouding tussen verzekerden, verzekeraar, zorgaanbieders en overheid meer directe ruilrelaties ('klantrelatie') tot stand konden worden gebracht (RVZ 2003: 59). Nog weer een andere interpretatie van marktwerking accentueerde het prijs- en financieringsaspect. In Publiek en privaat: mogelijkheden en gevolgen van private middelen in het publieke onderwijs onderzocht de Onderwijsraad de mogelijkheden voor 'private betrokkenheid en private financiering binnen het onderwijsbestel' (2001: 7). Hoewel zij stelde dat 'goed onderwijs een publiek belang is' waarbij 'de overheid verantwoordelijk [is] voor de financiering van toegankelijk en kwalitatief hoogwaardig onderwijs' (ibid.: 13), werd niettemin nagegaan wat de 'wensen, mogelijkheden en consequenties [zijn] van de inzet van private middelen in het publieke onderwijs' (ibid.: 15). In een sector waar marktwerking nog slechts beperkt toepasbaar was, werd het in eerste instantie alleen uitgelegd als een aanvullende bron van financiering.

In een laatste verschijningsvorm werd marktwerking ten slotte geïnterpreteerd als een onzichtbare hand die staat voor zelfregulatie, zelfsturing, of spontane ordening. Deze spontane orde werd tegenover directe overheidssturing geplaatst. Deze voorstelling kwam onder andere terug in het RVW-rapport Hoezo marktwerking (2004) waar werd voorgesteld om bij infrastructuurgebonden projecten meer te vertrouwen op zelforganisatie in plaats van overheidsregulering:

Veel meer dan nu het geval is, dient naar het oordeel van de Raad het zelforganiserend vermogen in de infrastructuurgebonden sectoren zelf te worden aangesproken: zowel aan de vraagzijde als aan de aanbodzijde. Dat heeft een aantal belangrijke voordelen ten opzichte van overheidsinterventie. (RVW 2004: 77)

Volgens de Raad bood zelforganisatie 'partijen meer ruimte dan in een van overheidswege dichtgeregelde sector om eigen afwegingen te maken en daarmee opties te ontwikkelen die voor iedereen meerwaarde bieden' en worden 'regels via zelfregulering sneller en soepeler [...] vastgelegd en gewijzigd dan in geval van overheidsregulering.'

Uit de voorgaande voorbeelden blijkt dat de adviesraden een divers metaforisch spel speelden met het begrip 'marktwerking' en dat daarmee een aantal uiteenlopende neoliberale performances gestalte kregen. De twee meest voorkomende vormen waren het vraag- of keuze-neoliberalisme en het concurrentie-neoliberalisme. Tegelijkertijd ontstonden echter ook vormen van aanbod-, privatisering-, commodificatie-, ruil-, prijs- of financieringsneoliberalisme, en een neoliberale rationaliteit gebaseerd op de onzichtbare hand. Deze performances droegen alle een onmiskenbaar neoliberaal karakter, omdat publieke taken in alle gevallen volgens marktprincipes werden georganiseerd hoe verschillend die marktprincipes ook werden geduid. Deze uiteenlopende 
duidingen verleenden aan de adviezen wel een sterk uiteenlopende politieke betekenis. Het vraag-neoliberalisme appelleerde aan politieke waarden zoals keuzevrijheid, de soevereiniteit van de burger of de wil van het volk. Het concurrentie-neoliberalisme beriep zich op noties als efficiëntie, diversiteit en innovatie, vrijwilligheid maar ook (zelf)discipline en selectiviteit. Het aanbodneoliberalisme benadrukte privaat initiatief en ondernemerschap, terwijl commodificatie-neoliberalisme publieke goederen en dienstverlening centraal stelde. Het ruil-neoliberalisme schoof juist het belang van sociale contracten en wederzijdse verantwoordelijkheid naar voren, terwijl het onzichtbare handneoliberalisme ten slotte suggereerde dat spontaan zelfbestuur een volwaardig alternatief vormde voor overheidssturing. Deze voorbeelden onderstrepen nog eens dat 'het' neoliberalisme bepaald geen eenduidig politiek project is, en dankzij een veelheid aan performances juist vele gezichten kent.

\section{Patroon 4: het borgen van publiek belang}

De analyse van de beleidsrapporten zou tot nu toe de indruk kunnen wekken dat het neoliberalisme een eindeloze variëteit kent, waardoor Nederlandse beleidsadviesraden wegbereiders zijn geworden van een ongebreideld, maar sterk gevarieerd neoliberalisme. Hoewel marktgerichte adviezen van de raden onderling inderdaad sterk variëren, vertrekken de adviezen echter wel vanuit een opvallend gelijksoortige probleemstelling. Telkens is de vraag hoe publieke belangen het best via 'de markt' behartigd kunnen worden. Zo stelde het rapport van de ROB niet alleen de vraag 'onder welke voorwaarden publieke dienstverlening onderhevig kan zijn aan marktwerking', maar onderzocht de Raad ook hoe 'de publieke verantwoordelijkheid bij het garanderen en faciliteren van de uitvoering van goederen en diensten door in de markt opererende organisaties' moest worden vormgegeven (1998: 8). De discussie over de neoliberale bestuursrationaliteiten vond dus plaats binnen een gedeeld kader dat in een WRR-rapport zo treffend 'het borgen van publiek belang' werd genoemd. In dat rapport werd betoogd dat het debat over de privatisering van verschillende overheidsdiensten verheldering behoefde. Volgens de WRR ging het erom

[...] hoe publieke belangen - dat wil zeggen maatschappelijke belangen waarvoor de overheid de eindverantwoordelijkheid op zich neemt - het beste zijn te 'borgen,' in de zin van 'beletten dat iets los of verloren gaat'. (WRR 2000: 9, cursivering toegevoegd)

Het begrip 'borgen' gaf uitdrukking aan de zorg dat publieke belangen door de toepassing van marktwerking in het gedrang konden komen. Daarom stelde de WRR een aantal 'borgingsmechanismen' voor die ingezet konden worden wanneer de private sector werd betrokken bij de uitvoering van publieke taken. De voorgestelde borgingsmechanismen waren regelgeving, concurrentie, het plaatsen 
onder overheidshiërarchie en institutionele borging door middel van professionele waarden. De WRR adviseerde dat de overheid beter moest toezien op de verankering van publieke belangen wanneer zij marktwerking als bestuursinstrument hanteerde. Het door de WRR gemunte kader van het 'borgen van publiek belang' vond nadien in veel andere adviesrapporten weerklank (bijv. OR 2001b; RVZ 2003a; RVZ 2003b; RVW 2003; RVW 2004). In 2004 erkende de RVW dan ook ruiterlijk: 'Mede als gevolg van een studie door de WRR is er de laatste jaren meer aandacht voor de consequenties die veranderingen in de marktordening (moeten) hebben voor de borging van publieke belangen' (2004: 27).

Het borgingskader groeide uit tot een centraal motief in de reflectie van beleidsadviesraden op de sluipende neoliberalisering van het beleid zoals deze zich in de jaren negentig had voltrokken. Deze reflectie was tweeledig. Enerzijds gaf zij blijk van aarzeling over de vermeende onzorgvuldige of ondoordachte invoering van marktwerking in het voorgaande decennium, vooral waar het de publieke sector betrof (bijv. WRR 2001: 17-18; RVW 2004: 11). Waar het publieke belang dreigde 'verloren te gaan,' probeerden de adviesraden het via 'borging' boven de markt te laten prevaleren. Toch was deze nadruk op borging eerder bedoeld als een aanscherping, dan als een afwijzing van neoliberale bestuurspraktijken. Marktwerking per se werd zeker niet afgewezen. Het ging er echter om deze logica sterker dienstig te maken aan het publiek belang. De borging bekrachtigde aldus neoliberale bestuursrationaliteiten door ze, uit hoofde van het algemeen belang, te domesticeren en weer sterker onder het mandaat van de overheid te brengen.

Zo beschouwd vormde het borgingskader een typisch Nederlandse vertolking van het neoliberalisme. In de literatuur wordt het neoliberalisme vaak in verband gebracht met een terugtredende overheid en een sterke anti-overheidspolitiek, zoals in de Amerikaanse variant (Foucault 2007; Foucault 2008; zie ook Mellink en Zuidhof 2020). Het Nederlandse borgingskader, waarin marktwerking in dienst werd gesteld van publieke overheidstaken, ging hier lijnrecht tegenin. Hiermee staat het wellicht dichter bij ordoliberale varianten van het neoliberalisme, waar de nadruk ligt op marktordening, maar verschilt het daarvan omdat het een liberale economische orde niet als einddoel ziet (zie ook Lemke 2001). Met de nadruk op het borgen van het publiek belang formuleerden de beleidsadviesraden een sterk overheidsgeleide variant van het neoliberalisme waarbij neoliberale bestuursrationaliteiten sterker dan voorheen ten dienste werden gesteld aan het behartigen van publieke belangen.

\section{Conclusie}

Om zicht te krijgen op de wijze waarop neoliberale bestuursrationaliteiten gestalte krijgen, werd in dit artikel onderzocht op welke wijze Nederlandse beleidsadviesraden in hun adviesrapporten reflecteerden op de veranderende verhouding tussen markt en overheid als gevolg van de marktwerkingsprojecten 
in de jaren negentig van de twintigste eeuw. Hieruit bleek dat de onderzochte rapporten expliciet ingingen op de nieuw ontstane, neoliberale vormen van bestuur, zoals die zich in die periode langzaam maar zeker in verschillende sectoren hadden gemanifesteerd.

Uit nadere analyse bleek dat de adviesrapporten zich niet simpelweg richtten op het vraagstuk van meer markt en minder overheid. In plaats daarvan richtten de adviezen zich op de vraag hoe 'markten' en marktwerking door overheden kunnen worden ingezet om publieke doelen te bereiken. In de rapporten stond dus niet een liberaal vraagstuk van marktregulering centraal, maar werd juist een neoliberale vraag onderzocht: op welke wijze waarop kunnen markten en marktwerking beter gebruikt worden om publieke taken uit te voeren?

Geconfronteerd met een nieuw, neoliberaal vraagstuk dat het gevolg was van een sluipende neoliberalisering in de jaren negentig, stelden de adviesraden zich vervolgens ten doel om een wetenschappelijk kader te bieden voor deze vragen. De wijze waarop de adviesraden vervolgens te werk gingen, geeft een goede indruk van de wijze waarop neoliberale bestuursrationaliteiten in algemene zin gestalte krijgen in de alledaagse politiek-bestuurlijke praktijk. Daaruit vallen vier conclusies te trekken.

Allereerst werd het neoliberale vraagstuk door de adviesraden sterk gedepolitiseerd behandeld. Conform hun formele opdracht benadrukten de adviesraden dat ze ideologie of politieke belangen wensten te vermijden. Hierdoor ontstond de neiging het neoliberale vraagstuk te reduceren tot een techno-politiek vraagstuk over hoe marktwerking het best toegepast kon worden toegepast. Het laat onder andere zien dat de verspreiding van neoliberale bestuursvormen in deze periode niet uitsluitend voortkwam uit ideologische vergezichten, politieke debatten of uitgesproken theoretische perspectieven, maar ook in belangrijke mate het gevolg was van dit soort pragmatische techno-politieke interventies van beleidsmakers (Mitchell 2002). Het techno-politieke karakter van deze beleidsinterventies vormt mogelijk ook een van de verklaringen voor het stilzwijgende karakter van de neoliberale revolutie in Nederland.

Ten tweede blijkt het geconstrueerde karakter van de 'markt' en 'marktwerking' een belangrijke rol te hebben gespeeld in de verbreiding van neoliberale bestuursrationaliteiten. De rapporten toonden het belang van een metaforisch spel rondom de 'markt' en het idee van 'marktwerking' voor de (lang niet altijd doelbewust beoogde) verspreiding van neoliberale bestuursvormen. Zoals de rapporten zelf beklemtoonden, ging het bij neoliberale vormen van bestuur niet om het creëren van 'echte' markten, maar om het scheppen van allerlei vormen van marktwerking. Dit gebeurde bijvoorbeeld door creatief te spelen met het idee van de markt, zoals het denken over concurrentie ('concurrentie om de markt in plaats van op de markt') of het te beprijzen goed (zoals bij de diagnosebehandelcombinaties). De inspiratie voor de verspreiding van het diverse palet van neoliberale vormen van bestuur in de jaren negentig hing ten nauwste samen met een dergelijk creatief gebruik van de marktmetafoor. 
Ten derde maakt de analyse duidelijk dat de besproken neoliberale beleidsinterventies heel ongelijkvormig waren en er geen eenduidig politiek programma in te onderkennen valt. De inventarisatie van de rapporten liet zien dat het creatieve spel met de 'markt' aanleiding gaf tot een veelheid van neoliberale performances. Deze neoliberale interventies verschilden van sector tot sector en er leken bovendien uiteenlopende politieke doelen mee te worden nagestreefd. Sommige performances benadrukten de vraagzijde van de markt en appelleerden aan politieke noties als keuzevrijheid en consumentensoevereiniteit, terwijl andere zich concentreerden op concurrentie en dan voldeden aan de politieke waarde van discipline, efficiëntie, zelfredzaamheid en kostenbeheersing. Zo konden uiteenlopende vormen van vraag-, concurrentie-, of commodificatie-neoliberalisme worden onderscheiden, evenals het onzichtbare hand-neoliberalisme. De neoliberalisering van de jaren negentig bleek zo een project met vele politieke gezichten. Deze diversiteit vormt een andere mogelijke verklaring voor de relatieve onzichtbaarheid van neoliberalisering in Nederland.

De laatste conclusie betreft de Nederlandse houding ten opzichte van de ingezette neoliberalisering van het beleid. Uit het belang dat adviesraden vanaf het jaar 2000 hechtten aan 'het borgen van publiek belang', bleek dat zij de neoliberalisering van beleid sterker onder de bestuurlijke regie van de overheid wilden brengen. De borgingsmetafoor drukte een zorg uit dat publieke belangen door marktwerking in het gedrang zouden kunnen komen. In de rapporten werden bovenal vormen van marktwerkingsbeleid voorgesteld waarin publieke belangen wél adequaat geborgd zouden zijn. De adviesraden keerden zich dus niet tegen neoliberale interventies, maar bepleitten een aanscherping ervan, waarbij het publieke belang niet uit het oog zou worden verloren. Met deze nadruk op het publiek belang, wijkt het af van de associatie van het neoliberalisme met een terugtredende overheid. Voor de beleidsadviesraden moest de neoliberale markt vooral een overheidsinstrument blijven. Het was daarmee exemplarisch voor de sterk op het publieke belang georiënteerde en overheidsgeleide wijze waarop het neoliberalisme haar opgang maakte in Nederland.

Deze analyse van de inbreng van beleidsadviesraden biedt een alternatief perspectief op de geschiedenis van het neoliberalisme waarin ideologische vergezichten, grote 'neoliberalen' of 'het neoliberalisme' als eenduidig politiek program een veel beperktere rol spelen. In plaats daarvan legt het een uiteenlopend veld van pragmatische, overheidsgestuurde neoliberale performances bloot, die veelal zijn omgeven met de nodige aarzeling. Daarmee wijst het op het belang van het bestuderen van de veelvormigheid en de alledaagse politieke achtergronden van de sluipende neoliberalisering in de jaren negentig. 


\section{Literatuur}

Achterhuis, H. (2010) De utopie van de vrije markt. Rotterdam: Lemniscaat.

Brown, W. (2015) Undoing the demos: Neoliberalism's stealth revolution. New York: Zone Books.

Burgin, A. (2012) The great persuasion: Reinventing free markets since the depression. Cambridge: Harvard University Press.

Foucault, M. (2007) Security, territory, population: Lectures at the Collège de France, 1977-78. (Graham Burchell (vert.), Michel Senellart (red.)) New York: Palgrave Macmillan.

Foucault, M. (2008) The birth of biopolitics: Lectures at the Collège de France, 1978-79. (Graham Burchell (vert.), Michel Senellart (red.)) New York: Palgrave Macmillan.

Harvey, D. (2005) A brief history of neoliberalism. Oxford: Oxford University Press.

Hoed, P. den (1995) Bestuur en beleid van binnenuit: Een analyse van instituties. Amsterdam: Boom.

Hoppe, R. en W. Halffman (2004) Wetenschappelijke beleidsadvisering in Nederland: Trends en ontwikkelingen. Beleidswetenschap, 31-61.

Jabko, N. (2006) Playing the market: A political strategy for uniting Europe, 1985-2005, Cornell studies in political economy. Ithaca: Cornell University Press.

Lemke, T. (2001) 'The birth of bio-politics': Michel Foucault's lecture at the College de France on neo-liberal governmentality. Economy and Society, 30(2): 190-207, DOI: http://dx.doi. org/10.1080/03085140120042271.

Mellink, B. en P.W. Zuidhof (2020) Market government: Neoliberalism and the transformative power of 1989. In: E. Braat en P. Corduwener (red.) 1989 and the West: Western Europe since the end of the Cold War. New York: Routledge, 123-140.

Ministerie van Economische Zaken (1994) Plan van Aanpak Marktwerking Deregulering en Wetgevingskwaliteit. Tweede Kamer 1994-1995, 24036, nr. 1.

Mirowski, P. (2013) Never let a serious crisis go to waste: How neoliberalism survived the financial meltdown. New York: Verso Books.

Mirowski, P. en D. Plehwe (2009) The road from Mont Pèlerin: The making of the neoliberal thought collective. Cambridge: Harvard University Press.

Mitchell, T. (2002) Rule of experts: Egypt, techno-politics, modernity. Berkeley: University of California Press.

Onderwijsraad, de (2001b) De Markt Meester? Een verkenning naar marktwerking in het onderwijs. 's-Gravenhage: de Onderwijsraad.

Oudenampsen, M. en B. Mellink (2019) Voorbij de controverse: Het Nederlandse neoliberalisme als onderwerp van onderzoek. Beleid en Maatschappij, 46(2): 235-254, DOI: 10.5553/ BenM/138900692019046002003.

Peck, J. (2010) Constructions of neoliberal reason. Oxford: Oxford University Press.

Reinhoudt, J. en S. Audier (2018) The Walter Lippmann Colloquium: The Birth of Neo-Liberalism. Cham: Palgrave Macmillan.

Slobodian, Q. (2018) Globalists: The end of empire and the birth of neoliberalism. Cambridge: Harvard University Press.

Steger, M.B. en R.K. Roy (2010) Neoliberalism: A very short introduction. Oxford: Oxford University Press. 
Zuidhof, P.W. (2012) Imagining Markets: The Discursive Politics of Neoliberalism Proefschrift, Erasmus Universiteit Rotterdam.

Zuidhof, P.W. (2014) Thinking Like an Economist: The Neoliberal Politics of the Economics Textbook. Review of Social Economy, 72(2): 157-185, DOI: 10.1080/00346764.2013.872952. Zuidhof, P.W. (2019) Behavioralizing Europe: Behavioral Economics Enters EU Policy Making. In: H.E. Strassheim en S. Beck (red.) Edward Elgar Handbook of Behavioral Change and Public Policy. Cheltenham: Edward Elgar Publishing, 163-178.

\section{P.W. Zuidhof}

P.W. Zuidhof is universitair hoofddocent Europese politieke economie bij de vakgroep Europese Studies van de Faculteit der Geesteswetenschappen aan de Universiteit van Amsterdam. Hij onderzoekt de geschiedenis en theorie van het neoliberalisme en richt zich vooral op de wijze waarop ideeën en technieken uit de economische wetenschap een rol spelen in het vormgeven van neoliberale vormen van bestuur. Recent onderzocht hij onder andere de opkomst van de toepassing van gedragseconomie binnen Europees beleid (2019), de geschiedenis van het beprijzen van havens in de EU (2019, samen met Thomas Vanoutrive) en de toepassing van het idee van emissiehandel (in voorbereiding). 


\section{Bijlage 1: Geraadpleegde adviesrapporten}

Raad

Raad voor de

Volksgezondheid

en Zorg (RVZ)

Raad voor het Openbaar

Bestuur (ROB)

Sociaal Economische

Raad (SER)

Raad voor Verkeer

en Waterstaat (RVW)
Jaar

1998

1998

1999

\section{Rapport}

Tussen Overheid en Markt. Zoetermeer.

Vraagstelling: Hoe kan het beste met de spanning tussen marktwerking en overheidsregulering worden omgegaan in de gezondheidszorg?

Betoog: Hoewel 'echte' marktwerking niet tot het leidende principe kan worden gemaakt, is het wel wenselijk om meer marktconforme werkwijze te kiezen onder de noemer van 'gedeeld bestuur'.

Marktaspecten: vraagsturing; belang van consument; keuzevrijheid; kostenbeheersing.

De Overheid de markt in- of uitprijzen. 's-Gravenhage. Vraagstelling: Onder welke voorwaarden kan publieke dienstverlening aan marktwerking onderhevig zijn? Betoog: De introductie van marktwerking bij de uitvoering van publieke taken houdt risico's in voor doelmatige en rechtmatige uitvoering en vraagt daarom om goed toezicht. Marktaspecten: keuzevrijheid; efficiëntie; innovatie.

Markt en Overheid. 's-Gravenhage.

Vraagstelling: Welke regelgeving is benodigd om de marktactiviteiten van overheden te reguleren.

Betoog: Marktactiviteiten van de overheid kunnen alleen plaatsvinden zolang daar een wettelijke basis aan ten grondslag ligt en het leidt tot bewezen maatschappelijke welvaartsvoordelen en er afdoende toezicht is.

Marktaspecten: concurrentie als gelijk speelveld.

Meer Markt, Andere Overheid: Advies over de veranderende relatie tussen markt en overheid op terreinen van Verkeer en Waterstaat. 's-Gravenhage.

Vraagstelling: Onder welke voorwaarden kan het marktmechanisme beter dan de overheid voorzien in het aanbod van infrastructurele diensten op gebied van personenverkeer en telecommunicatie? Betoog: De markt is onder omstandigheden beter in staat om in te spelen op wensen van consument, is efficiënter en kan innovatie stimuleren, maar dit vraagt om een minder 
presterende en meer voorwaardenscheppende overheid.

Marktaspecten: concurrentie; efficiëntie; innovatie.

Wetenschappelijke Raad voor het Regeringsbeleid (WRR)

Onderwijsraad (OR)

Raad voor Verkeer en

Waterstaat en Algemene Energie raad (RVW)
Het Borgen van Publiek Belang. 's-Gravenhage.

Vraagstelling: Hoe moeten in een context van toegenomen privatisering, de publieke en private verantwoordelijkheden worden toegedeeld bij het behartigen van publieke belangen?

Betoog: Het rapport stelt een aantal verschillende mechanismen voor (regels, concurrentie, hiërarchie en institutionele waarden) die kunnen worden toegepast om de publieke belangenbehartiging te borgen. Daarbij moet de overheid de rol van marktmeester op zich nemen. Marktaspecten: concurrentie; private sector.

Publiek en Privaat: Mogelijkheden en Gevolgen van Private Middelen in het Publieke Onderwijs. 's-Gravenhage.

Vraagstelling: Wat zijn wensen, mogelijkheden en consequenties van de inzet van private middelen in het publieke onderwijs? Betoog: Private middelen dienen zorgvuldig te worden behandeld en hebben uitsluitend een aanvullend karakter. Marktaspecten: bron van financiering; private sector.

Zorgvuldig Omgaan met de Introductie van Marktwerking rond Vitale Infrastructurele Voorzieningen. 's-Gravenhage. Vraagstelling: Welke lessen kunnen geleerd worden van recente negatieve ervaringen met de wijze waarop marktwerking geïntroduceerd wordt in infrastructurele voorzieningen?

Betoog: Aangezien de voordelen van marktwerking niet vanzelf gerealiseerd worden, is er voor het borgen van de publieke belangen behoefte aan een beter analysekader, meer aandacht voor het veranderingsproces, en de mogelijke risico's.

Marktaspecten: concurrentie; private sector; vraagprikkels.

Raad voor de

Volksgezondheid

en Zorg (RVZ)
Van Patiënt tot Klant. Zoetermeer.

Vraagstelling: Welke voorwaarden, middelen en prikkels zijn nodig om zorgaanbieders meer vraaggericht te laten werken?

Betoog: Bevorder het ontstaan van klantrelaties (ideaal in de vorm van betaalrelaties) tussen patiënten en 
zorgaanbieders. Waar dergelijke relaties niet rechtstreeks mogelijk zijn, bevorder dan alternatieve relaties zoals in de vorm van PGB's of patiëntenorganisaties.

Marktaspecten: ruilrelatie; betaalrelatie; keuzevrijheid.

Raad voor de

$2003 b$

Volksgezondheid

en Zorg (RVZ)

Raad voor Verkeer

en Waterstaat (RVW)

Raad voor de

Volksgezondheid

en Zorg (RVZ)
Hoezo Marktwerking? 's-Gravenhage.

Vraagstelling: Hoe kunnen de publieke belangen geborgd worden en hoe moet effectief trajectmanagement plaatsvinden bij veranderingen in de marktordening van infrastructuurgebonden sectoren.

Betoog: aangezien echte markten voor

infrastructuurgebonden sectoren nauwelijks realiseerbaar zijn, dienen de publieke belangen vooraf geëxpliciteerd te worden en dient er effectief trajectmanagement georganiseerd te worden, en daarbij moet gestreefd worden naar een juiste balans tussen zelforganisatie en zelfregulering en geïnstitutionaliseerd toezicht. Marktaspecten: vraagprincipe; onzichtbare hand; zelfregulering.

Gepaste Zorg. Zoetermeer.

Vraagstelling: Op welke wijze kunnen de kosten voor gezondheidszorg, bijvoorbeeld door prikkels voor patiënten en zorgverleners, beheerst worden in een omgeving waarin sprake is van marktgerichte zorg en verzekering en kostenbeheersing niet meer identiek is aan budgettering en aanbodregulering?

Betoog: Adequate informatie, nog meer dan financiële prikkels, kan eraan bijdragen dat zorgvragers de gepaste zorg 
zullen vragen.

Marktaspecten: informatie; kostenbeheersing; vraagsturing; keuzevrijheid.

Sociaal-Economische

2005

Raad (SER)
Ondernemerschap voor de publieke zaak. 's-Gravenhage. Vraagstelling: Onder welke voorwaarden kan maatschappelijk ondernemerschap de publieke dienstverlening verbeteren en wat is daarbij de rol van de overheid?

Betoog: Door het stimuleren van ondernemerschap kan de voorziening van diensten met een publiek belang worden verbeterd en draagt dit bij aan een doelmatige levering van kwalitatief goede diensten, meer innovatie in dienstverlening en meer maatwerk en meer keuzevrijheid voor afnemers.

Marktaspecten: ondernemerschap; innovatie; keuzevrijheid. 